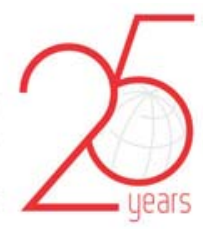

\title{
Effectiveness of various irrigation protocols for the removal of calcium hydroxide from artificial standardized grooves
}

\section{Abstract}

Hakan GOKTURK ${ }^{1}$

Ismail OZKOCAK ${ }^{1}$

Feyzi BUYUKGEBIZ1

Osman DEMIR ${ }^{2}$
Submitted: August 17, 2016 Modification: October 5, 2016

Accepted: October 17, 2016
Corresponding address: Hakan Gokturk

Department of Endodontics - Faculty of Dentistry Gaziosmanpasa University - 60100 - Tokat - Turkey Phone: +90-356-2124222 - ext-4015 Fax: +90-356-2124225 e-mail: gokturk82@hotmail.com
Objective: The aim of this study was to investigate the ability of laseractivated irrigation ( $\mathrm{LAI}$ ), XP-endo Finisher, CanalBrush, Vibringe, passive ultrasonic irrigation (PUI), and conventional syringe irrigation systems on the removal of calcium hydroxide $(\mathrm{CH})$ from simulated root canal irregularities. Material and Methods: The root canals of one hundred and five extracted single-rooted teeth were instrumented using Reciproc rotary files up to size R40. The teeth were split longitudinally. Two of the three standard grooves were created in the coronal and apical section of one segment, and another in the middle part of the second segment. The standardized grooves were filled with $\mathrm{CH}$ and the root halves were reassembled. After 14 days, the specimens were randomly divided into 7 experimental groups ( $n=15 /$ group). $\mathrm{CH}$ was removed as follows: Group 1: beveled needle irrigation; Group 2: double sidevented needle irrigation; Group 3: CanalBrush; Group 4: XP-endo Finisher; Group 5: Vibringe; Group 6: PUI; Group 7: LAl. The amount of remaining $\mathrm{CH}$ in the grooves was scored under a stereomicroscope at $20 \times$ magnification. Statistical evaluation was performed using Kruskal-Wallis and BonferroniCorrection Mann-Whitney U tests. Results: Groups 1 and 2 were the least efficient in eliminating $\mathrm{CH}$ from the grooves. Groups 6 and 7 eliminated more $\mathrm{CH}$ than the other protocols; however, no significant differences were found between these two groups ( $P>.05$ ). Conclusions: Nevertheless, none of the investigated protocols were able to completely remove all $\mathrm{CH}$ from all three root regions. LAI and PUI showed less residual $\mathrm{CH}$ than the other protocols from artificial grooves.

Keywords: Calcium hydroxide. Endodontics. Lasers. Sodium hypochlorite. Ultrasonic therapy.
${ }^{1}$ Gaziosmanpasa University, Faculty of Dentistry, Department of Endodontics, Tokat, Turkey. ${ }^{2}$ Gaziosmanpasa University, Faculty of Medicine, Department of Biostatistics, Tokat, Turkey. 


\section{Introduction}

Chemomechanical preparation is the first step to eliminate microorganisms in the root canal system, but it alone is not sufficient to clean the root canal. Ex vivo and clinical studies have indicated that intact areas remain on root canal walls during mechanical preparation, and therefore, it is important to perform irrigation in addition to mechanical preparation ${ }^{15,23}$ For this purpose, several different irrigation solutions, medicaments and techniques have been used ${ }^{10,11,14}$.

Calcium hydroxide $(\mathrm{CH})$ is widely used as an intracanal medicament between appointments to increase the number of canals free from bacteria because of its antibacterial, therapeutic, biocompatible, and regenerative properties ${ }^{4,26}$. However, the remnant $\mathrm{CH}$ hinders the penetration of disinfectants and sealers into dentinal tubules and compromises the seal of the canal filling ${ }^{17,22}$. Therefore, residual $\mathrm{CH}$ must be removed before permanent root canal obturation is completed $^{8}$. In most cases, the residual $\mathrm{CH}$ was removed following copious irrigation with sodium hypochlorite $(\mathrm{NaOCl})$ and ethylenediaminetetraacetic acid (EDTA) in combination with the use of master apical file (MAF) or gutta-percha up to working length $(W L)^{24}$. Different irrigation techniques and devices were used to activate and improve the effectiveness of irrigation solutions $7,10,14,25$.

A novel irrigation instrument, the XP-endo Finisher, has been introduced by FKG, Dentaire SA ( La Chauxde-Fonds, Switzerland). This instrument's design is similar to an ISO size \#25, 0.00 taper NiTi file. According to manufactures, this file improves the penetration of irrigation solutions to the irregular area of root canal system by expanding its reach $6 \mathrm{~mm}$ in diameter ${ }^{3,29}$.

Although previous studies demonstrated efficacy of sonic and ultrasonic systems on debris and $\mathrm{CH}$ removal ${ }^{8,10,28}$, sufficient information is not yet available in the literature concerning XP-endo Finisher ${ }^{31}$ and laser-activated irrigation (LAI). Therefore, the aim of this study was to compare the effect of XP-endo Finisher, sonic, ultrasonic and LAI and conventional syringe irrigation techniques in removing $\mathrm{CH}$ from simulated lateral irregularities on the root canal wall. The null hypotheses were that the removal of $\mathrm{CH}$ was not affected by irrigation technique [1] or the [2] section of root canal (third).

\section{Material and methods}

Ethical approval was obtained from the Clinical Research Ethics Committee of the Faculty of Medicine of Gaziosmanpasa University (project number: 15KAEK-229). One hundred and five human maxillary incisors were used in this study. Mesiodistal and bucco-palatal direction radiographs were taken from the teeth to confirm the presence of a single canal. The teeth were decoronated using straight diamond burs (Komet, Gebr. Brasseler GmbH \& Co. KG, Germany) in a conventional high-speed handpiece under water cooling so that each root had a standardized length of $15 \mathrm{~mm}$. The WL was determined to be $1 \mathrm{~mm}$ short of the apex using a \#10 K file (VDW GmbH, Munich, Germany). The WL was established at $14 \mathrm{~mm}$. Roots were prepared with Reciproc rotary files up to size R40 at WL (VDW GmbH, Germany) and irrigation was performed with $10 \mathrm{~mL} 2.5 \% \mathrm{NaOCl}$. Next, roots were placed in Eppendorf tubes (Labosel, İstanbul, Turkey) filled with a silicone material (Zetaplus soft; Zhermack Clinical, Badia Polesine, Italy). After removal of the roots from the impression material, a longitudinal groove was prepared on the buccal and lingual surface using a narrow diamond bur without cutting the canal wall. A spatula was used to split longitudinally. A number 15 cavitron tip (Aceton, Merignac, France) was modified and inserted into an ultrasonic handpiece (Newtron P5; Satelec, Acteongroup, France) to create artificial standardized grooves. Two of the three standard grooves were created in the coronal and apical part of one segment, and another in the middle part of a second segment. The dimensions of grooves were $0.2 \mathrm{~mm}$ in width, $3 \mathrm{~mm}$ in length, and $0.5 \mathrm{~mm}$ in depth (Figure 1). The dimension of grooves was checked under a stereomicroscope (Zeiss Stemi 2000C, Carl Zeiss Microlmaging, Göttingen, Germany) at 20X magnification. The root halves and grooves were irrigated with $5 \mathrm{~mL}$ of $17 \%$ EDTA for $1 \mathrm{~min}$. and 5 $\mathrm{mL} 2.5 \% \mathrm{NaOCl}$ for 1 min. while being activated with a toothbrush to remove debris and the smear layer. The standardized grooves were filled with $\mathrm{CH}$ paste (Ammdent, Punjab, India), and the root halves were reassembled. The root canals were fully filled with $\mathrm{CH}$ paste using a Lentulo spiral. Two radiographs (mesiodistal and bucco-palatal direction) were taken to confirm complete filling of the canals with $\mathrm{CH}$ paste. Roots were remounted and placed into Eppendorf tubes. Then samples were divided randomly into 7 
groups, each containing 15 teeth. Seven different color stickers were pasted on the caps of the Eppendorf tubes to indicate each of the 7 groups. The access cavities were sealed with temporary filling material (Cavit, 3M ESPE, Seefeld, Germany) and stored in $37^{\circ} \mathrm{C}$ at $100 \%$ relative humidity for 2 weeks.

After 14 days, the $\mathrm{CH}$ was removed as follows: first, an R40 file (VDW, Germany) at WL and $1 \mathrm{~mL}$ $2.5 \% \mathrm{NaOCl}$ was used to obtain a space for irrigation needles and instruments.

Group 1- Beveled needle irrigation: The root canals were irrigated with $10 \mathrm{~mL} 2.5 \% \mathrm{NaOCl}$ for $2 \mathrm{~min}$. via 27-gauge beveled dental irrigation needle (Ayset, Adana, Turkey). The needle tip was placed $1 \mathrm{~mm}$ short of the WL.

Group 2- Double side-vented needle irrigation: The root canals were irrigated with $10 \mathrm{~mL} 2.5 \% \mathrm{NaOCl}$ for 2 min. via a 30-gauge double side-vented needle (i-Tips, i dental, Siauliai, Lithuania). The needle tip was placed $1 \mathrm{~mm}$ short of the WL.

Group 3- CanalBrush: The root canals were irrigated with $5 \mathrm{~mL} 2.5 \% \mathrm{NaOCl}$ and then brushed with a medium size CanalBrush (Coltene/Whaledent GmbHCo. KG, Langenau, Germany) at 600 rpm for 1 min. A final flush was done with $5 \mathrm{~mL} 2.5 \% \mathrm{NaOCl}$. CanalBrushes were inserted $1 \mathrm{~mm}$ short of the $\mathrm{WL}$ and moved with small vertical movements.

Group 4- XP-endo Finisher: I rrigation protocol was same as Group 3 with the exception that the XP-endo Finisher (FKG, Dentaire Sa, La Chaux-de- Fonds, Switzerland) was used instead of the CanalBrush at $800 \mathrm{rpm}$ with $1 \mathrm{Ncm}$ for $1 \mathrm{~min}$. The file tip was placed $1 \mathrm{~mm}$ short of the WL.

Group 5- Sonic I rrigation (Vibringe): A $10 \mathrm{~mL}$ 2.5\% $\mathrm{NaOCl}$ was delivered and sonically activated via the Vibringe system (Vibringe B. V. Corp, Amsterdam, Netherlands). The needle tip was placed $1 \mathrm{~mm}$ short of the WL without touching the canal walls, enabling it to vibrate freely for $2 \mathrm{~min}$.

Group 6- Passive ultrasonic irrigation (PUI): Irrigation protocol was the same as Group 3, with the exception that the passive ultrasonic activation was performed using an I rrisafe ultrasonic tip ( size 25, 0.02 taper) (Satelec Acteongroup, France) that was placed $1 \mathrm{~mm}$ short of the WL. A power setting of 9 was used for duration of $1 \mathrm{~min}$. A $10 \mathrm{~mL} 2.5 \% \mathrm{NaOCl}$ solution continuously delivered at a flow rate of approximately $0.16 \mathrm{~mL} \mathrm{~s}^{-1}$ through the unit.

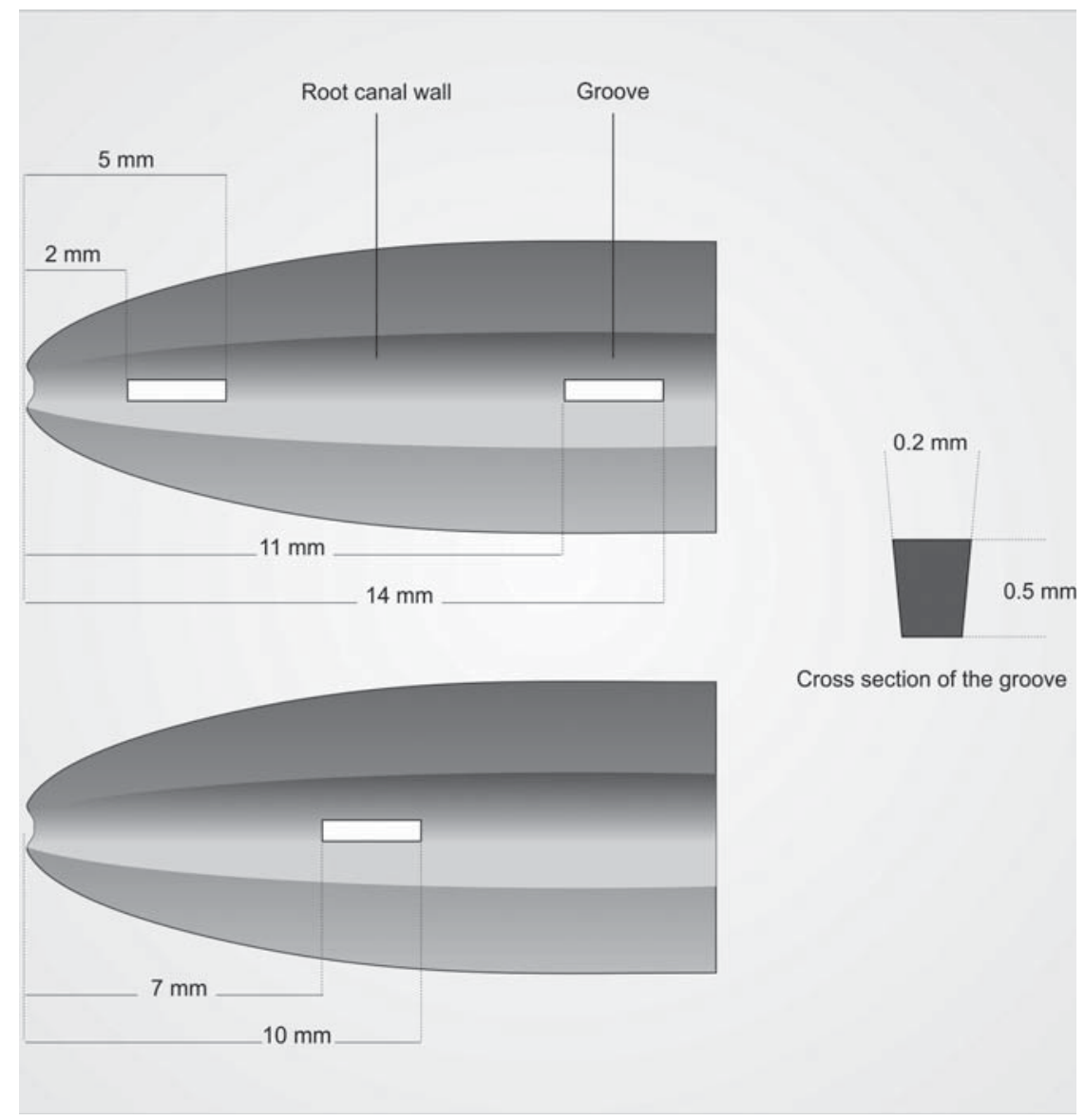

Figure 1- A schematic representation of the location and size of the longitudinal grooves 
Group 7- Er:YAG laser-activated irrigation: The irrigation solution was activated with the same protocol as in Group 3, with the exception that an Er:YAG laser (Kavo Key 3+, KaVo, Biberach, Germany) with a 2940 $\mathrm{nm}$ wavelength for $1 \mathrm{~min}$. was used with endodontic tips (a $28 \mathrm{~mm}$ long and diameter ISO 30) in place of a CanalBrush. Laser parameters were $1 \mathrm{~W}, 10 \mathrm{~Hz}, 100$ $\mathrm{mJ}$, and an energy density of $142.8 \mathrm{~J} / \mathrm{cm}^{2}$. The laser tip was inserted into canal at $1 \mathrm{~mm}$ short of the WL. When the root canal irrigant dropped or vaporized, the canal space was filled with $2.5 \% \mathrm{NaOCl}$.

For each specimen, $11 \mathrm{~mL}$ of $2.5 \% \mathrm{NaOCl}$ was used as irrigation solution and was delivered at a flow rate of approximately $0.08 \mathrm{~mL} \mathrm{~s}-1$ except for G6 (PUI). The irrigant was delivered into the canal with a double sidevented needle (i dental, Lithuania) except for Group

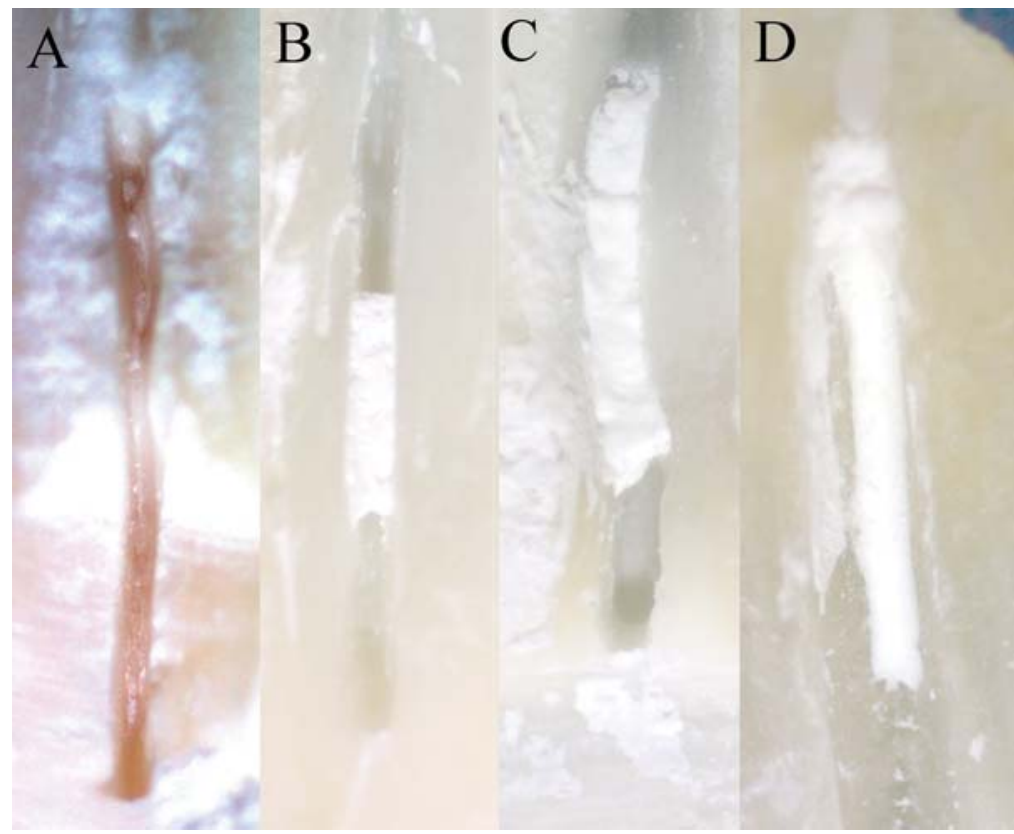

Figure 2- Scores of $\mathrm{Ca}(\mathrm{OH}$ ) remnants: (A) Score 0 (group 7 at apical region); (B) Score 1 (group 6 at middle region); (C) Score 2 (group 5 at coronal region); (D) Score 3 (group 1 at apical region)

Table 1- Multiple comparisons according to root canal regions

\begin{tabular}{|c|c|c|c|c|c|c|c|}
\hline \multirow[b]{2}{*}{ Scores } & & \multirow[b]{2}{*}{0} & \multirow[b]{2}{*}{1} & \multirow[b]{2}{*}{2} & \multirow[b]{2}{*}{3} & \multicolumn{2}{|c|}{$\begin{array}{c}\text { Kruskal-Wallis statistical } \\
\text { analysis }\end{array}$} \\
\hline & & & & & & Median[IQR] & $P$ \\
\hline $\begin{array}{l}\text { Group } 1 \\
\text { (Beveled } \\
\text { Needle) }\end{array}$ & $\begin{array}{l}\text { Coronal } \\
\text { Middle } \\
\text { Apical }\end{array}$ & $\begin{array}{l}- \\
- \\
-\end{array}$ & $\begin{array}{l}- \\
- \\
-\end{array}$ & $\begin{array}{l}8 \\
5 \\
1\end{array}$ & $\begin{array}{c}7 \\
10 \\
14\end{array}$ & $\begin{array}{l}2[2-3]^{\mathrm{a}} \\
3[2-3]^{\mathrm{ab}} \\
3[3-3]^{\mathrm{b}}\end{array}$ & 0.023 \\
\hline $\begin{array}{c}\text { Group } 2 \\
\text { (Double Side - } \\
\text { Needle) }\end{array}$ & $\begin{array}{l}\text { Coronal } \\
\text { Middle } \\
\text { Apical }\end{array}$ & $\begin{array}{l}- \\
- \\
-\end{array}$ & - & $\begin{array}{c}10 \\
5 \\
2\end{array}$ & $\begin{array}{c}5 \\
10 \\
13\end{array}$ & $\begin{array}{l}2[2-3]^{\mathrm{a}} \\
3[2-3]^{\mathrm{ab}} \\
3[3-3]^{\mathrm{b}}\end{array}$ & 0.011 \\
\hline $\begin{array}{c}\text { Group } 3 \\
\text { (CanalBrush) }\end{array}$ & $\begin{array}{l}\text { Coronal } \\
\text { Middle } \\
\text { Apical }\end{array}$ & - & $\begin{array}{l}- \\
3 \\
1\end{array}$ & $\begin{array}{c}14 \\
9 \\
7\end{array}$ & $\begin{array}{l}1 \\
3 \\
7\end{array}$ & $\begin{array}{l}2[2-2] \\
2[2-2] \\
2[2-3]\end{array}$ & 0.098 \\
\hline $\begin{array}{l}\text { Group } 4 \text { (XP- } \\
\text { endo Finisher }\end{array}$ & $\begin{array}{l}\text { Coronal } \\
\text { Middle } \\
\text { Apical }\end{array}$ & $\begin{array}{l}- \\
- \\
-\end{array}$ & $\begin{array}{l}4 \\
4 \\
-\end{array}$ & $\begin{array}{l}11 \\
9 \\
7\end{array}$ & $\begin{array}{l}- \\
2 \\
8\end{array}$ & $\begin{array}{l}2[1-2]^{\mathrm{a}} \\
2[1-2]^{\mathrm{a}} \\
3[2-3]^{\mathrm{b}}\end{array}$ & 0.001 \\
\hline $\begin{array}{l}\text { Group } 5 \\
\text { (Vibringe) }\end{array}$ & $\begin{array}{l}\text { Coronal } \\
\text { Middle } \\
\text { Apical }\end{array}$ & $\begin{array}{l}- \\
- \\
-\end{array}$ & $\begin{array}{l}2 \\
1 \\
-\end{array}$ & $\begin{array}{c}13 \\
12 \\
8\end{array}$ & $\begin{array}{l}- \\
2 \\
7\end{array}$ & $\begin{array}{l}2[2-2]^{\mathrm{a}} \\
2[2-2]^{\mathrm{ab}} \\
2[2-3]^{\mathrm{b}}\end{array}$ & 0.004 \\
\hline Group 6 (PUI) & $\begin{array}{l}\text { Coronal } \\
\text { Middle } \\
\text { Apical }\end{array}$ & $\begin{array}{l}7 \\
7 \\
1\end{array}$ & $\begin{array}{l}5 \\
5 \\
7\end{array}$ & $\begin{array}{l}3 \\
3 \\
7\end{array}$ & $\begin{array}{l}- \\
- \\
-\end{array}$ & $\begin{array}{l}1[0-1]^{\mathrm{a}} \\
1[0-1]^{\mathrm{a}} \\
1[1-2]^{\mathrm{b}}\end{array}$ & 0.029 \\
\hline Group 7 (LAI) & $\begin{array}{l}\text { Coronal } \\
\text { Middle } \\
\text { Apical }\end{array}$ & $\begin{array}{l}6 \\
6 \\
2\end{array}$ & $\begin{array}{l}6 \\
8 \\
5\end{array}$ & $\begin{array}{l}3 \\
1 \\
8\end{array}$ & $\begin{array}{l}- \\
- \\
-\end{array}$ & $\begin{array}{l}1[0-1]^{\mathrm{ab}} \\
1[0-1]^{\mathrm{a}} \\
2[1-2]^{\mathrm{b}}\end{array}$ & 0.022 \\
\hline
\end{tabular}

Different lowercase letters indicate statistically significant difference 
1 (beveled needle). The amount of remaining $\mathrm{CH}$ in the grooves was evaluated under a stereomicroscope (Zeiss Stemi 2000-C, Germany) at 20× magnification and equipped with a digital camera (AxioCam ERc5s, Germany) by two calibrated endodontists using an numeric evaluation scale described by van der Sluis, et al. ${ }^{30}$ (2007). The scoring system was as follows: score 0 , the groove is entirely empty; score $1, \mathrm{CH}$ is present in less than $50 \%$ of the groove; score $2, \mathrm{CH}$ is present in more than $50 \%$ of the groove, but not completely; and score 3 , the groove is completely covered with $\mathrm{CH}$ (Figure 2). Evaluation was conducted based on the color codes by two endodontists blinded to the group number. Before scoring, the two endodontists assessed 50 randomly selected specimens simultaneously for calibration purposes. In the case of discrepant scores, a consensus was reached by discussion.
Kruskal-Wallis test was used to compare the nonnormal data among groups. For multiple comparisons between the pair-wise groups, Bonferroni-Correction Mann Whitney $U$ test was used. A p-value <.05 was considered significant. The kappa coefficient was used to determine interexaminer agreement. Analyses were performed using SPSS 19 (IBM SPSS Statistics 19, SPSS Inc., Somers, NY).

\section{Results}

Results of the two examiners were in good agreement (kappa value $=0.897)$. Comparisons between the groups are presented in Tables 1 and 2. Elimination of $\mathrm{CH}$ was more difficult from the

Table 2- Multiple comparisons between groups

\begin{tabular}{|c|c|c|c|c|c|c|c|}
\hline \multirow[b]{2}{*}{ Scores } & & \multirow[b]{2}{*}{0} & \multirow[b]{2}{*}{1} & \multirow[b]{2}{*}{2} & \multirow[b]{2}{*}{3} & \multicolumn{2}{|c|}{$\begin{array}{c}\text { Kruskal-Wallis statistical } \\
\text { analysis }\end{array}$} \\
\hline & & & & & & Median[IQR] & $\mathrm{P}$ \\
\hline \multirow{7}{*}{ Coronal } & $\begin{array}{l}\text { Beveled } \\
\text { Needle }\end{array}$ & - & - & 8 & 7 & $2[2-3]^{a c}$ & \multirow{7}{*}{$<.001$} \\
\hline & $\begin{array}{l}\text { Double Side - } \\
\text { Needle }\end{array}$ & - & - & 10 & 5 & $2[2-3]^{\mathrm{ac}}$ & \\
\hline & CanalBrush & - & - & 14 & 1 & $2[2-2]^{\mathrm{ac}}$ & \\
\hline & $\begin{array}{l}\text { XP-endo } \\
\text { Finisher }\end{array}$ & - & 4 & 11 & - & $2[1-2]^{\mathrm{bc}}$ & \\
\hline & Vibringe & - & 2 & 13 & - & $2[2-2]^{\mathrm{ac}}$ & \\
\hline & PUI & 7 & 5 & 3 & - & $1[0-1]^{\mathrm{b}}$ & \\
\hline & LAI & 6 & 6 & 3 & - & $1[0-1]^{\mathrm{b}}$ & \\
\hline \multirow{7}{*}{ Middle } & $\begin{array}{l}\text { Beveled } \\
\text { Needle }\end{array}$ & - & - & 5 & 10 & $3[2-3]^{a}$ & \multirow{7}{*}{$<.001$} \\
\hline & $\begin{array}{l}\text { Double Side - } \\
\text { Needle }\end{array}$ & - & - & 5 & 10 & $3[2-3]^{a}$ & \\
\hline & CanalBrush & - & 3 & 9 & 3 & $2[2-2]^{a}$ & \\
\hline & $\begin{array}{l}\text { XP-endo } \\
\text { Finisher }\end{array}$ & - & 4 & 9 & 2 & $2[1-2]^{a c}$ & \\
\hline & Vibringe & - & 1 & 12 & 2 & $2[2-2]^{a}$ & \\
\hline & PUI & 7 & 5 & 3 & - & $1[0-1]^{\mathrm{bc}}$ & \\
\hline & LAI & 6 & 8 & 1 & - & $1[0-1]^{\mathrm{b}}$ & \\
\hline \multirow{7}{*}{ Apical } & $\begin{array}{l}\text { Beveled } \\
\text { Needle }\end{array}$ & - & - & 1 & 14 & $3[3-3]^{a}$ & \multirow{7}{*}{$<.001$} \\
\hline & $\begin{array}{l}\text { Double Side - } \\
\text { Needle }\end{array}$ & - & - & 2 & 13 & $3[3-3]^{a}$ & \\
\hline & CanalBrush & - & 1 & 7 & 7 & $2[2-3]^{a}$ & \\
\hline & $\begin{array}{l}\text { XP-endo } \\
\text { Finisher }\end{array}$ & - & - & 7 & 8 & $3[2-3]^{a}$ & \\
\hline & Vibringe & - & - & 8 & 7 & $2[2-3]^{a}$ & \\
\hline & PUI & 1 & 7 & 7 & - & $1[1-2]^{\mathrm{b}}$ & \\
\hline & LAI & 2 & 5 & 8 & - & $2[1-2]^{\mathrm{b}}$ & \\
\hline
\end{tabular}

Different lowercase letters indicate statistically significant difference 
apical region. None of the irrigation protocols could completely remove all remnant of $\mathrm{CH}$ in all three root regions. Beveled needle irrigation (Group 1) and double side-vented needle irrigation (Group 2) were the significantly least efficient on the elimination of $\mathrm{CH}$ from the grooves $(\mathrm{P}<.001)$. PUI (Group 6) and Er:YAG laser-activated irrigation (Group 7) removed more $\mathrm{CH}$ than the other protocols in all thirds of the root; however, no significant differences were found between these two groups $(P>.05)$. No significant differences were found between XP-endo Finisher (Group 4) and PUI (Group 6) at the coronal and middle regions $(P>.05)$. The Kruskal-Wallis test showed significant differences between the groups for coronal, middle, and apical thirds $(P<.05)$, except for the CanalBrush (Group 3) (P>.05).

\section{Discussion}

I rrigation has an important role in controlling endodontic infection and debridement of the root canal system. $\mathrm{CH}$ is a widely used intracanal medicament as it creates a physical barrier from microorganisms and avoids the development of reinfections. However, previous studies have shown that removal of $\mathrm{CH}$ before the completion of the root canal obturation increased the sealer penetration into the dentinal tubules, and thus provided a good seal and also strengthens the bond between dentine and sealer ${ }^{6,11}$.

In the practice of endodontics, many different irrigation methods are used for this purpose. In this study, the effectiveness of different irrigation techniques on $\mathrm{CH}$ removal was evaluated. In the literature, calculation of the residual amount of $\mathrm{CH}$ remaining in the root canal were made by calculating the area of the remnant on dentin wall, by scoring, SEM analysis, volume analysis with spiral $\mathrm{CT}$, and by using a micro- $\mathrm{CT}^{5,25,30,32}$. We preferred the scoring method described in the study by van der Sluis, et al. ${ }^{30}$ (2007) because it is a simple and easily accessible technique and used in many previous studies ${ }^{1,8}$.

$\mathrm{CH}$ powder was mixed with liquid and used in paste form in this study. Lambrianidis, et al. ${ }^{18}$ (1999) used $\mathrm{CH}$ medications at $42 \%$ and $95 \%$ concentrations in their study and reported that $\mathrm{CH}$ content in the paste had no effect on removal from the root canal wall.

A commonly suggested method for removal of $\mathrm{CH}$ is the irrigation with $\mathrm{NaOCl}$ and EDTA accompanied by very light instrumentation and the use of $\operatorname{MAF}^{19,25}$. Many techniques have been proposed to increase the efficiency of the irrigation solution. Mechanical agitation with a handpiece, gutta-percha or plastic tools, sonic and ultrasonic activation are also suggested techniques. In addition, LAI is another efficient and current method ${ }^{13,21}$. Kenee, et al. ${ }^{16}$ (2006) removed $\mathrm{CH}$ by four different procedures and demonstrated that the use of hand files and irrigation solution alone was not very effective on the removal of $\mathrm{CH}$.

Capar, et al. ${ }^{8}$ (2014) compared $\mathrm{CH}$ removal efficiency of EndoVac, Self-Adjusting File (SAF), PUI and conventional irrigation techniques from artificial standardized grooves. They reported that PUI was more effective than other groups when $\mathrm{NaOCl}$ was used. Ahmetoglu, et al. ${ }^{1}$ (2013) compared $\mathrm{CH}$ removal efficiency of PUI, SAF and conventional irrigation methods by SEM. Researchers found that PUI was more effective than SAF and traditional irrigation. These results support our research. PUI technique is based on the transmission of acoustic energy to an irrigation solution. The agitation increases the penetration of irrigant to the irregular canal areas and the $\mathrm{CH}$ removal capacity of the irrigation solution. Similarly, van der Sluis, et al. ${ }^{30}$ (2007) investigated the efficiency of $\mathrm{CH}$ removal of various irrigation processes and found that PUI with $\mathrm{NaOCl}$ was more effective than PUI with water and syringe irrigation with $\mathrm{NaOCl}$.

In this study, the effectiveness of different activation protocols of irrigation solutions were compared between themselves and with traditional irrigation methods. The results are consistent with the findings of the above-mentioned authors. According to our results, LAl and PUI were more effective in the elimination of $\mathrm{CH}$ in all 3 regions of the root canal. Therefore, the null hypothesis [1] that no differences would occur among the different irrigation techniques in terms of $\mathrm{CH}$ removal was rejected. In addition, no difference was found between $\mathrm{PUI}$ and XP-endo Finisher groups in the coronal and middle third regions. Although CanalBrush and sonic-activated irrigation exhibited lower scores than needle irrigation groups, the difference was not statistically significant. Results of our study indicate that there was a significant difference between sections of the root canal in terms of $\mathrm{CH}$ removal except for the CanalBrush group; therefore, the second null hypothesis is also rejected.

Despite results by Balvedi, et al. ${ }^{5}$ (2010), who stated PUI was more effective in terms of $\mathrm{CH}$ removal 
than syringe irrigation in the coronal and middle third regions, no statistically significant difference was found between the two irrigation regimes in the apical third. In the aforementioned study, researchers mixed $\mathrm{CH}$ with different liquids and preferred saline solution to the irrigant. In this study, $\mathrm{CH}$ was mixed with only distilled water and $2.5 \% \mathrm{NaOCl}$ was used as the irrigation solution. The reason for the differences between the studies may be the various solutions and $\mathrm{CH}$ vehicle used. Similar to our findings, a recent systematic review showed the superiority of PUI over syringe irrigation on the removal of $\mathrm{CH}$ from the apical part of root canals ${ }^{10}$.

Wiseman, et al. ${ }^{32}$ (2011) evaluated the efficacy of $\mathrm{CH}$ removal with sonic irrigation and ultrasonic irrigation in the mesial root canal of mandibular molars by using the same volume irrigant $(6 \% \mathrm{NaOCl}+14 \%$ EDTA) and same time interval. Authors found PUI repeated 3 times with $20 \mathrm{sec}$. intervals was more effective than sonic irrigation. This study's results are similar to the findings of Wiseman, et al. ${ }^{32}$ (2011), who found PUI was superior to sonic irrigation, although a different duration and irrigation regime was applied.

Tasdemir, et al. ${ }^{27}$ (2011) evaluated the use of $\mathrm{NaOCl}$ and $\mathrm{NaOCl}+\mathrm{EDTA}$ with different agitation techniques (CanalBrush, PUI, MAF) on the removal of $\mathrm{CH}$ Although the type of solution did not influence the $\mathrm{CH}$ removal, CanalBrush and PUI were found statistically more effective than other techniques. Our results were not consistent with the findings of the aforementioned study. Although CanalBrush removed more $\mathrm{CH}$ than the needle groups, this difference was not statistically significant. Another difference is that the PUI removed significantly more $\mathrm{CH}$ than CanalBrush in all three root regions. Tasdemir, et al. ${ }^{27}$ (2011) used field measurement methods as opposed to our study that utilized a preferred scoring method with a PUI time interval of $1 \mathrm{~min}$.

Alturaiki, et al. ${ }^{2}$ (2015) compared the $\mathrm{CH}$ removal capacity of EndoVac, sonic, ultrasonic activated irrigation techniques with conventional irrigation. Researchers reported that no statistically significant difference was found between sonic and ultrasonic irrigation in the coronal and middle third regions, but found that sonic irrigation was more efficient in the apical region. Our results do not coincide with the results of these authors. The differences between this outcome and our results may reflect different variables in the study design, such as (i) the sonic device used and (ii) the MAF size. Researchers used EndoActivator (Dentsply Tulsa Dental Specialties, Tulsa, OK), $\mathrm{NaOCl}$ and EDTA in combination and prepared root canals up to \#45 MAF. In this study, root canals were prepared up to \#40 MAF and only $2.5 \% \mathrm{NaOCl}$ was activated via Vibringe system. However, Bolles, et al. ${ }^{7}$ (2013) stated that no significant differences were found between EndoActivator and Vibringe systems on the sealer penetration into dentinal tubules. Further investigations are needed to clarify the effectiveness of these devices in removing medicaments.

$\mathrm{Li}$, et al. ${ }^{21}$ (2015) compared $\mathrm{CH}$ removal efficacy of conventional needle irrigation, sonic, ultrasonic activated irrigation, and Photon-Induced Photoacoustic Streaming methods in root canals and isthmuses. Study results showed that laser and ultrasonic activated irrigation protocols were the most effective methods on the elimination of $\mathrm{CH}$ in both apical region and isthmuses. The findings of $\mathrm{Li}$, et al. ${ }^{21}$ (2015) support the results of our research. According to our results, PUI was the most effective method for removal of $\mathrm{CH}$ than needle irrigation techniques in all three root regions. In addition, no statistically significant difference was found between XP-endo Finisher and PUI groups in the coronal and middle regions of root canals. However, Leoni, et al. ${ }^{20}$ (2016) stated that no significant differences were found between PUI and $\mathrm{XP}$-endo Finisher in removing debris from root canal surface.

The XP-endo Finisher is newly introduced NiTi file to improve efficacy of final irrigation procedure. The canal must be shaped at least ISO 25 file to use XPendo Finisher. The instrument is stabile in martensite form at room temperature and can be bent to the desired shape. The instrument changes its phase to austenite when the temperature reaches the body temperature ${ }^{3,29}$. We believe that only one study ${ }^{31}$ compared the effectiveness of the XP-endo Finisher on $\mathrm{CH}$ removal. In contrast to our findings, Wigler, et al. ${ }^{31}$ (2016) reported that no significant difference was found between PUI and XP-endo Finisher on the removal of $\mathrm{CH}$ from simulated irregularities in the apical third of root canals. However, previous studies showed its superior debris removal ability from the root canal walls 3,20 .

The apical third exhibited higher amounts of residual $\mathrm{CH}$ than the coronal and middle thirds in all experimental groups, except for LAI. This finding is in line with the results of previous studies ${ }^{12,21}$. This 
observation may be related to accumulation and transfer of residual $\mathrm{CH}$ to the apical region, which has smaller canal area and smaller volume of irrigation solution, as well as the anatomic complexity of apical third ${ }^{9,12}$. The action and circulation of irrigants may therefore be hindered.

\section{Conclusion}

The activation of $\mathrm{NaOCl}$ with different instruments enhanced $\mathrm{CH}$ removal. Nevertheless, none of the investigated protocols were able to completely remove the $\mathrm{CH}$ from all three root regions. LAI and PUI methods removed more $\mathrm{CH}$ than the other protocols from artificial grooves in all thirds of the root canal.

\section{References}

1- Ahmetoğlu F, Şimşek N, Keleş A, Ocak MS, Er K. Efficacy of selfadjusting file and passive ultrasonic irrigation on removing calcium hydroxide from root canals. Dent Mater J. 2013;32(6): 1005-10.

2- Alturaiki S, Lamphon $\mathrm{H}$, Edrees $\mathrm{H}$, Ahlquist M. Efficacy of 3 different irrigation systems on removal of calcium hydroxide from the root canal: a scanning electron microscopic study. J Endod. 2015;41(1):97-101. 3- Alves FR, Marceliano-Alves MF, Sousa JC, Silveira SB, Provenzano JC, Siqueira JF Jr. Removal of root canal fillings in curved canals using either reciprocating single- or rotary multi-instrument systems and a supplementary step with the XP-Endo Finisher. J Endod. 2016; 42(7): 1114-9.

4- Athanassiadis B, Abbott PV, Walsh LJ. The use of calcium hydroxide, antibiotics and biocides as antimicrobial medicaments in endodontics. Aust Dent J. 2007; 52:S64-82.

5- Balvedi RP, Versiani MA, Manna FF, Biffi JC. A comparison of two techniques for the removal of calcium hydroxide from root canals. Int Endod J. 2010;43(9): 763-8.

6- Bodrumlu E, Avsar A, Hazar Bodrumlu E, Cicek E. The effects of calcium hydroxide removal methods on bond strength of Epiphany SE with two irrigation protocols. Acta Odontol Scand. 2013;71(34): 989-93.

7- Bolles JA, He J, Svoboda KK, Schneiderman E, Glickman GN. Comparison of Vibringe, EndoActivator, and needle irrigation on sealer penetration in extracted human teeth. J Endod. 2013;39(5): 708-11.

8- Capar ID, Ozcan E, Arslan H, Ertas H, Aydinbelge HA. Effect of different final irrigation methods on the removal of calcium hydroxide from an artificial standardized groove in the apical third of root canals. J Endod. 2014;40(3):451-4.

9- Elnaghy AM, Mandorah A, Elsaka SE. Effectiveness of XP-endo Finisher, EndoActivator, and file agitation on debris and smear layer removal in curved root canals: a comparative study. Odontology. 2017; 105(2): 178-83.

10- Ethem Yaylali I, Kececi AD, Ureyen Kaya B. Ultrasonically activated irrigation to remove calcium hydroxide from apical third of human root canal system: a systematic review of in vitro studies. J Endod. 2015; 41(10): 1589-99.
11- Gorduysus M, Nagas E, Torun OY, Gorduysus O. A comparison of three rotary systems and hand instrumentation technique for the elimination of Enterococcus faecalis from the root canal. Aust Endod J. $2011 ; 37(3): 128-33$

12- Gorduysus M, Yilmaz Z, Gorduysus O, Atila B, Karapinar SO. Effectiveness of a new canal brushing technique in removing calcium hydroxide from the root canal system: a scanning electron microscope study. J Conserv Dent. 2012;15(4):367-71.

13- Gu LS, Kim JR, Ling J, Choi KK, Pashley DH, Tay FR. Review of contemporary irrigant agitation techniques and devices. J Endod. 2009; 35(6): 791-804

14- Haapasalo M, Shen Y, Wang Z, Park E, Curtis A, Patel P, et al. Apical pressure created during irrigation with the GentleWave ${ }^{\mathrm{TM}}$ system compared to conventional syringe irrigation. Clin Oral Investig. 2016; 20: 1525-34

15- Hülsmann M, Peters OA, Dummer PM. Mechanical preparation of root canals: shaping goals, techniques and means. Endod Topics. 2005; 10(1): 30-76.

16- Kenee DM, Allemang JD, Johnson JD, Hellstein J, Nichol BK. A quantitative assessment of efficacy of various calcium hydroxide removal techniques. J Endod. 2006; 32(6):563-5.

17- Kim SK, Kim YO. Influence of calcium hydroxide intracanal medication on apical seal. Int Endod J. 2002;35(7):623-8.

18- Lambrianidis T, Kosti E, Boutsioukis C, Mazinis M. Removal efficacy of various calcium hydroxide/chlorhexidine medicaments from the root canal. Int Endod J. 2006; 39(1):55-61.

19- Lambrianidis T, Margelos J, Beltes P. Removal efficiency of calcium hydroxide dressing from the root canal. J Endod. 1999;25(2):85-8. 20- Leoni GB, Versiani MA, Silva-Sousa YT, Bruniera JF, Pécora JD, Sousa-Neto MD. Ex vivo evaluation of four final irrigation protocols on the removal of hard-tissue debris from the mesial root canal system of mandibular first molars. Int Endod J. 2017;50(4):398-406.

21- Li D, Jiang S, Yin X, Chang JW, Ke J, Zhang C. Efficacy of needle, ultrasonic, and endoactivator irrigation and photon-induced photoacoustic streaming in removing calcium hydroxide from the main canal and isthmus: an in vitro micro-computed tomography and scanning electron microscopy study. Photomed Laser Surg. 2015;33(6): 330-7.

22- Ozkocak I, Sonat B. Evaluation of effects on the adhesion of various root canal sealers after Er:YAG laser and irrigants are used on the dentin surface. J Endod. 2015;41(8): 1331-6.

23- Peters OA, Schönenberger K, Laib A. Effects of four Ni-Ti preparation techniques on root canal geometry assessed by micro computed tomography. Int Endod J. 2013;4(3):221-30.

24- Phillips M, McClanahan S, Bowles W. A titration model for evaluating calcium hydroxide removal techniques. J Appl Oral Sci. 2015;23:94100.

25- Salgado RJ, Moura-Netto C, Yamazaki AK, Cardoso LN, Moura AA Prokopowitsch I. Comparison of different irrigants on calcium hydroxide medication removal: microscopic cleanliness evaluation. Oral Surg Oral Med Oral Pathol Oral Radiol Endod. 2009; 107(4):580-4.

26- Siqueira JF J r, Magalhães KM, Rôças IN. Bacterial reduction in infected root canals treated with $2.5 \% \mathrm{NaOCl}$ as an irrigant and calcium hydroxide/camphorated paramonochlorophenol paste as an intracanal dressing. J Endod. 2007; 33:667-72.

27- Tasdemir T, Celik D, Er K, Yildirim T, Ceyhanli KT, Yeşilyurt C. Efficacy of several techniques for the removal of calcium hydroxide medicament from root canals. Int Endod J. 2011;44:505-9.

28- Topçuoglu HS, Akti A, Düzgün S, Ceyhanli KT, Topçuoglu G. Effectiveness of different irrigation procedures for removal of dentin debris from a simulated internal resorption cavity. Int J Artif Organs. 2015; 38: 165-9.

29- Trope M, Debelian G. XP-3D Finisher ${ }^{T M}$ file - the next step in restorative endodontics. Endodontic Practice US. 2015; 8: 22-24. 
30- Van der Sluis LW, Wu MK, Wesselink PR. The evaluation of removal of calcium hydroxide paste from an artificial standardized groove in the apical root canal using different irrigation methodologies. Int Endod J. 2007;40(1):52-7.

31- Wigler R, Dvir R, Weisman A, Matalon S, Kfir A. Efficacy of XP-endo finisher files in the removal of calcium hydroxide paste from artificial standardized grooves in the apical third of oval root canals. Int Endod J. 2016 Jun 8. doi: 10.111/iej.12668. Epub ahead of print.
32- Wiseman A, Cox TC, Paranjpe A, Flake NM, Cohenca N, Johnson JD. Efficacy of sonic and ultrasonic activation for removal of calcium hydroxide from mesial canals of mandibular molars: a microtomographic study. J Endod. 2011;37(2):235-8. 